\title{
A forecast of international migration flows into EU countries until 2050
}

\begin{abstract}
The subject of this paper is international migration into EU countries. The research objective is a quantitative estimation of the volume of international migration flows into European countries and their close neighbors until 2050. The forecast of international migration flows is based on the author's own model of global international migration. The model is based on a synergetic approach and assumptions that the level of migration is determined first of all by the number of existing migrants from that country. The data used for the forecast is UN data on migration flows in 1990-2015, and the UN's predictions regarding changes in population between now and 2050. The forecast is based on the medium scenario of demographic development offered by the UN. Countries with a current population of more than 5 million are taken into consideration as potential sources of immigration. The predicted values of the total number of international migration flows to each of the EU and neighboring countries for each five-year period until 2050 are determined. The predicted migration flows from EU countries are also determined. It is concluded that the forecasts allow us to claim that the problem of migration will continue for EU countries. However, the essence of this problem is not the prevention of excess migration, but attracting migrants to the countries of the 'second Europe.'
\end{abstract}

Key words: forecasts of international migration flows until 2050, simulation of international migration, migration to the EU

\section{Introduction}

$\mathbf{M}$ anaging international migration is a generally recognized problem for the world. Nowadays, there are many theoretical views regarding causes and factors relating to migration. Various macro- and micro-level neoclassical theories are being gradually replaced by more complex and perhaps more realistic theories. These include the NELM-theory - the theory of the new economics of labor migration, the theory of the 'dual labor market,' the world system theory, the theory of migration networks, the transnational migration theory, the theory of cumulative causation, and others (Davis, 1988, pp. 245-261). Each of the theories more or less systematically creates its own hierarchy of factors that affect migration flows at a macro- or micro-level. Numerous detailed and complex models are built according to these theories. However, it should be admitted that the increasing detail of theoretical concepts makes it difficult to construct predictive models that could be based on these theories (Alvarez-Plata, Brücker, Siliverstovs, 2003 , p. 68; Raymer, 2013, pp. 801-819). When attempting even medium-term forecasting, defining the parameters of such a model becomes almost impossible. Consequently, such models do not enable us to construct a method for predicting the dynamics of world migration for a period of ten to thirty years (World, 2002).

Consequently, in contrast to the prevailing approaches regarding further detailing of migratory flows and volumes within certain groups of countries or regions, we consider 
it necessary to turn to a global assessment of the expected migration flows in the medium and long term.

The task of this paper is to describe a modeled forecast of the quantity of international migration flows into the European countries and their close neighbors until 2050, based on the prediction of migration flows between countries of the world and analyzing the predicted potential for international migration. The forecast is based on UN models of change in world population by 2050 (World, 2015). The research is based on the model of global international migration created by the author, which is based on a synergetic approach.

\section{Data characteristics and base assumptions of the forecast}

For the forecast, data from the Population Division of the Department of Economic and Social Affairs of the United Nations Secretariat was used (Trends, 2015). The UN data includes information on the total number of international migrants per country and territory with uncertain status (232 countries in total) for 1990, 1995, 2000, 2005, 2010, and 2015. This means that, in the case of UNPD data, we are dealing with somewhat heterogeneous cumulative data on migrants. Due to the UN data being constantly updated we preferred the UNPD data released in 2015, on which we based our assessment of the numbers of potential migrants (Trends, 2015).

The UNPD also provides data for three scenarios - low, medium and high - for forecasting population size by 2100 (World, 2015). Medium scenario data was used, limiting our attempts to provide a forecast by 2050 . The grounds for using only the medium scenario of the UNDP data are discussed in our paper (Polovyi, 2017). Only countries with a current population of more than five million are considered as significant targets and sources of international migrants.

In contrast to the more common approach, in this model the concepts of supplier countries and recipient countries are abandoned. Each country in the model, before and during every iteration, is considered both as a potential supplier and as a potential recipient of international migrants. The ascending hypothesis in constructing this model of migration flows is the assumption that it is possible to determine the degree of mutual attraction for migration flows between pairs of countries at a certain moment, which will determine the direction and intensity of migration flows for the next forecasted period.

The model of international migration takes into consideration the fact that the potential attraction of migrants to a country depends on the following factors:

- the presence and relative size of a diaspora from the source country in the potential destination country;

- the presence and relative number of immigrants from other countries in the potential destination country;

- the dynamics of the increase in the number of immigrants in a potential destination country, and the ratio between the increase in the number of immigrants from each country and the increase from all countries.

The volume of potential migration flows in each pair of 'migration interactions' between countries is influenced by the presence and relative number of 'extra people' in a potential supplier country. This is determined by: 
- the ratio between the available population in the given country and the number of people who emigrated from it during the last observation period;

- the population size and rate of population growth in a given country.

Thus, in model terms, 'extra people' are those who are potentially ready for emigration, based on the trends of migration from this country in past periods of observation, and those who are 'doomed to emigration' by existing socio-demographic trends in a given country. Consequently, these are individuals who are expected to emigrate from a given country in the forecasted period. It should be noted that the model we created as a result of the data used is adapted to estimate the extent of legal migration. The forecasts based on it are not intended to provide forecasts of illegal, or, for example, seasonal production migration. Forecasts of migration flows are formed for five-year periods, from 2020 to 2050.

Verification of the model based on materials from 2010 was described in another article (Polovyi, 2017). The model represents the flows of migration between 118 countries with a population of more than five million people and takes into account $95 \%$ of the actual migration between all of these countries. For the purposes of this paper, migration links between these 118 countries and the European countries and their close neighbors are considered. The EU member states and several non-EU states bordering and/or closely related to the EU countries - Norway, Switzerland, Serbia, Ukraine, Belarus, and Russia - were taken into consideration as the targets of migration flows.

\section{Predicted levels of international migration flows}

With the help of the created model, the matrices of the paired indexes of the mutual attractiveness of EU countries for migrants were developed for each fifth year from 2020 to 2050. Based on these matrices and in accordance with the UN's medium scenario of demographic development, a scenario for forecasting trends and volumes of legal migration for every five years up to 2050 was constructed, considering all EU (and neighboring) countries and the countries evaluated as a source of migration. The predicted values of the total number of international migrants in each of the EU countries until 2050 were determined.

The tables containing the predicted number of migrants by country until 2040 are posted on the websites http://myko.name/forecasts/ and https://independent.academia. edu/FieldNick. Let us consider the obtained results of the forecast for the above-mentioned EU and neighboring countries.

The total number of immigrants in the studied European countries will increase from 64 million in 2015 to 80 million people in 2050. On average, the proportion of international migrants in these countries is:

- in $2015-9 \%$ migrants (out of the total population);

- in $2050-12 \%$ migrants.

In 2015, the largest number of migrants was in Germany, France, Britain, Spain, and Italy; ranging from 11 to 5 million, in descending order; and 10 million in the Russian Federation. In 2050, the largest number of migrants is predicted to be found in almost the same countries - Germany (13 million), France (10.7 million), Britain (8.1 million), 
and Spain (5.8 million). However, Switzerland will take 4th position among the countries that have accepted the largest number of migrants. Russia, which will receive the largest number of migrants - more than 13 million - is outside our rating and taken only for comparison.

Analysis of the number of international migrants in relation to the total population of the countries is more informative. In 2015, the percentage of migrants in the European countries' populations ranges from $25 \%$ (Switzerland) to $0.6 \%$ (Romania). In 2050, the change in the percentage of migrants in relation to the total population of the country is predicted to range from $50 \%$ (Switzerland) to $0.8 \%$ (Serbia).

Let us consider the detailed distribution of countries by the percentage of migrants in their population: in 2015, the top five countries in terms of the percentage of international migrants were Switzerland (25.5\% migrants out of the total population), Sweden (14.4\%), Austria (14.2\%), Germany (14.1\%), and Norway (12.2\%). My forecast is that in 2030 the composition of top five countries with the highest percentage of international migrants will change to Switzerland (34\%), Belgium (19\%), Germany (15\%), Austria $(15 \%)$, and the Netherlands (15\%).

As we can see, Belgium and the Netherlands are moving fast to the top of the list. In 2040, an even greater percentage of migrants is predicted in Belgium and the Netherlands. The top five countries will be Switzerland (42\%), Belgium (23\%), the Netherlands (19\%), Germany (16\%), and Austria (15\%).

In 2050, the top five countries with the largest number of migrants replicate the configuration of 2040. It will be: Switzerland (50\%), Belgium (27\%), the Netherlands (24\%), Germany (18\%), and Austria (15\%). But, let it be noted, according to the forecast, even in 2050 there are not many countries in which the percentage of international migrants exceeds numbers usual for today (Table 1).

Table 1

Ratio (in \%) of the number of migrants to total population [as forecasted by the $\mathrm{UN}$ ]*

\begin{tabular}{|c|c|c|c|c|c|c|c|c|}
\hline & 2015 (fact) & 2020 & 2025 & 2030 & 2035 & 2040 & 2045 & 2050 \\
\hline 1 & 2 & 3 & 4 & 5 & 6 & 7 & 8 & 9 \\
\hline Austria & 14.19 & 15.15 & 15.32 & 15.23 & 15.16 & 15.15 & 15.17 & 15.23 \\
\hline Belarus & 10.84 & 10.99 & 11.20 & 11.47 & 11.78 & 12.09 & 12.39 & 12.67 \\
\hline Belgium & 11.59 & 1388 & 16.34 & 18.55 & 20.67 & 22.76 & 24.82 & 26.88 \\
\hline Bulgaria & 1.27 & 1.41 & 1.47 & 1.54 & 1.62 & 1.71 & 1.80 & 1.89 \\
\hline Czech Republic & 3.66 & 4.24 & 4.67 & 5.08 & 5.53 & 5.97 & 6.41 & 6.85 \\
\hline Denmark & 8.58 & 8.76 & 8.76 & 8.65 & 8.52 & 8.41 & 8.33 & 8.24 \\
\hline Finland & 4.47 & 5.1 & 5.65 & 6.22 & 6.83 & 7.46 & 8.12 & 8.79 \\
\hline France & 11.43 & 12.05 & 12.67 & 13.31 & 13.70 & 14.12 & 14.60 & 15.11 \\
\hline Germany & 14.03 & 14.45 & 14.82 & 15.26 & 15.77 & 16.33 & 16.96 & 17.65 \\
\hline Greece & 6.06 & 6.13 & 6.23 & 6.34 & 6.45 & 6.56 & 6.69 & 6.84 \\
\hline Hungary & 4.4 & 5.19 & 6.35 & 7.57 & 8.84 & 10.15 & 11.49 & 12.86 \\
\hline Italy & 8.33 & 8.34 & 8.37 & 8.43 & 8.49 & 8.57 & 8.68 & 8.81 \\
\hline Netherlands & 9.72 & 10.96 & 13.08 & 15.22 & 17.33 & 19.45 & 21.59 & 23.73 \\
\hline Norway & 12.2 & 12.95 & 12.69 & 12.23 & 11.83 & 11.50 & 11.20 & 10.92 \\
\hline Poland & 1.41 & 1.41 & 1.43 & 1.46 & 1.50 & 1.54 & 1.59 & 1.64 \\
\hline Portugal & 6.74 & 7.36 & 8.03 & 8.57 & 9.15 & 9.83 & 10.62 & 11.56 \\
\hline Romania & 0.62 & 0.73 & 0.82 & 0.88 & 0.91 & 0.94 & 0.98 & 1.02 \\
\hline
\end{tabular}




\begin{tabular}{|l|r|r|r|r|r|r|r|r||}
\hline \multicolumn{1}{|c|}{1} & \multicolumn{1}{|c|}{2} & \multicolumn{1}{c|}{3} & \multicolumn{1}{c|}{4} & \multicolumn{1}{c|}{5} & \multicolumn{1}{c|}{6} & \multicolumn{1}{c||}{7} & \multicolumn{1}{c|}{8} & \multicolumn{1}{c|}{9} \\
\hline Russian Federation & 7.06 & 7.43 & 7.85 & 8.32 & 8.83 & 9.34 & 9.81 & 10.27 \\
\hline Serbia & 0.65 & 0.66 & 0.67 & 0.69 & 0.71 & 0.73 & 0.76 & 0.78 \\
\hline Slovakia & 3.17 & 3.57 & 3.93 & 4.10 & 4.19 & 4.28 & 4.39 & 4.50 \\
\hline Spain & 12.18 & 12.17 & 12.23 & 12.34 & 12.44 & 12.56 & 12.72 & 12.95 \\
\hline Sweden & 14.37 & 14.49 & 14.27 & 14.00 & 13.74 & 13.47 & 13.18 & 12.89 \\
\hline Switzerland & 25.54 & 27.87 & 30.78 & 34.17 & 38.00 & 42.09 & 46.12 & 49.98 \\
\hline Ukraine & 9.32 & 9.57 & 9.86 & 10.22 & 10.63 & 11.05 & 11.47 & 11.90 \\
\hline $\begin{array}{l}\text { United Kingdom of Great } \\
\text { Britain and Northern Ireland }\end{array}$ & 10.9 & 11.19 & 11.16 & 11.06 & 10.97 & 10.89 & 10.81 & 10.76 \\
\hline
\end{tabular}

* Countries alphabetically.

Source: Trends, 2015 and the author's model.

In addition to the five leaders, ten more countries (including Ukraine, Belarus and Russia) will have more than $10 \%$ of international migrants in their population by 2050 ; these countries are France, Spain, Sweden, Hungary, Belarus, Ukraine, Portugal, Norway, and the United Kingdom of Great Britain and Northern Ireland.

It is interesting to note that throughout the period from 2015 to 2050, Ukraine and Belarus remain in the middle of the list, with a range of 9-12\% international migrants in their populations. At the same time, at the beginning of the considered period, all Eastern European EU member states are at the bottom of the list, with a proportion of migrants of $0.6-4 \%$. According to our forecast, only Hungary will actively replenish its population with foreign migrants, and by 2050 it will overtake several Western European countries in terms of the ratio of migrants in its population, including Portugal, the United Kingdom, and Italy.

It should also be noted that, according to our forecast, any significant increase in the actual number of international migrants before 2050 will occur only in the following countries (Table 2): France, the Russian Federation, Switzerland, the Netherlands, and Belgium - by more than 2 million people; Germany, the United Kingdom of Great Britain and Northern Ireland, and Hungary - by more than half a million people. Finally, in six more countries, the forecasted increase in the number of international migrants before 2050 will be more than one hundred thousand people: Portugal, the Czech Republic, Finland, Spain, Austria, and Sweden. In other countries, the increase in the percentage of international migrants will be caused not so much by the increase in their absolute number, but by the decrease in the predicted local population.

Table 2

Forecast of the number of international migrants (sorted by total number of new migrants until 2050) (in millions)

\begin{tabular}{|l|r|r|r|r|r|r|r|r|c|}
\hline & $\begin{array}{c}\mathbf{2 0 1 5} \\
\text { (fact) }\end{array}$ & $\mathbf{2 0 2 0}$ & $\mathbf{2 0 2 5}$ & $\mathbf{2 0 3 0}$ & $\mathbf{2 0 3 5}$ & $\mathbf{2 0 4 0}$ & $\mathbf{2 0 4 5}$ & $\mathbf{2 0 5 0}$ & $\begin{array}{c}\text { Total number of } \\
\text { new migrants in } \\
\text { the country ar- } \\
\text { riving 2015-2050 }\end{array}$ \\
\hline \multicolumn{1}{|c|}{1} & \multicolumn{1}{|c|}{2} & \multicolumn{1}{|c|}{3} & \multicolumn{1}{|c|}{4} & \multicolumn{1}{|c|}{5} & \multicolumn{1}{c|}{6} & \multicolumn{1}{c|}{7} & \multicolumn{1}{c|}{8} & 9 & 10 \\
\hline France & 7.36 & 7.92 & 8.48 & 9.05 & 9.46 & 9.88 & 10.31 & 10.75 & 3.39 \\
\hline Russian Federation & 10.13 & 10.62 & 11.09 & 11.54 & 11.98 & 12.41 & 12.81 & 13.20 & 3.07 \\
\hline Switzerland & 2.12 & 2.41 & 2.76 & 3.15 & 3.59 & 4.07 & 4.54 & 5.01 & 2.89 \\
\hline Netherlands & 1.64 & 1.88 & 2.28 & 2.68 & 3.07 & 3.45 & 3.82 & 4.18 & 2.53 \\
\hline
\end{tabular}




\begin{tabular}{|l|r|r|r|r|r|r|r|r|c|}
\hline \multicolumn{1}{|c|}{1} & \multicolumn{1}{c|}{3} & \multicolumn{1}{c|}{4} & \multicolumn{1}{c|}{5} & \multicolumn{1}{c|}{6} & \multicolumn{1}{c|}{7} & \multicolumn{1}{c|}{8} & \multicolumn{1}{c|}{9} & 10 \\
\hline Belgium & 1.31 & 1.61 & 1.93 & 2.23 & 2.52 & 2.80 & 3.09 & 3.37 & 2.06 \\
\hline Germany & 11.32 & 11.62 & 11.85 & 12.10 & 12.36 & 12.63 & 12.89 & 13.15 & 1.83 \\
\hline $\begin{array}{l}\text { United Kingdom of Great } \\
\text { Britain and Northern Ireland }\end{array}$ & 7.05 & 7.46 & 7.65 & 7.76 & 7.84 & 7.93 & 8.02 & 8.11 & 1.06 \\
\hline Hungary & 0.43 & 0.50 & 0.60 & 0.70 & 0.80 & 0.89 & 0.98 & 1.07 & 0.64 \\
\hline Portugal & 0.70 & 0.75 & 0.80 & 0.84 & 0.89 & 0.94 & 1.00 & 1.07 & 0.37 \\
\hline Czech Republic & 0.39 & 0.45 & 0.49 & 0.53 & 0.57 & 0.61 & 0.65 & 0.68 & 0.30 \\
\hline Finland & 0.25 & 0.28 & 0.32 & 0.36 & 0.39 & 0.43 & 0.47 & 0.51 & 0.26 \\
\hline Spain & 5.62 & 5.62 & 5.64 & 5.67 & 5.70 & 5.73 & 5.77 & 5.80 & 0.19 \\
\hline Austria & 1.21 & 1.31 & 1.34 & 1.35 & 1.35 & 1.35 & 1.35 & 1.35 & 0.14 \\
\hline Sweden & 1.41 & 1.47 & 1.49 & 1.51 & 1.52 & 1.52 & 1.53 & 1.53 & 0.13 \\
\hline
\end{tabular}

Source: Trends, 2015 and the author's model.

Let us briefly consider the states which are the main sources of international migrants for the countries of the EU. We will describe only the meaningful data for a few countries.

- Switzerland: in 2020, the main sources of international migrants in Switzerland will be Germany, Italy, Portugal, France, Serbia, Turkey, Austria, Spain, and Brazil. Nationals of these countries will make up more than $80 \%$ of all international migrants in Switzerland. In 2050, $80 \%$ of the predicted 5 million foreign migrants in Switzerland will be made up of nationals from just six countries. These are Germany, Italy, Portugal, Austria, France, and Serbia.

- Belgium: in 2020, almost $90 \%$ of international migrants in Belgium will be from France, the Netherlands, Italy, Romania, Morocco, Poland and Spain. In 2050, more than $80 \%$ of the predicted 3.3 million foreign migrants in Belgium will come from Romania, the Netherlands, Bulgaria, Guinea, France, Italy and Morocco. It is worth noting that Poland, for example, will not be among the main sources of migration into Belgium.

- The Netherlands: this country is characterized by the extreme fuzziness of its sources of international migrants. Thus, in $2020,80 \%$ of the international migrants in the Netherlands will come from 11 countries: Poland, Turkey, Morocco, Indonesia, Germany, the Russian Federation, China, Belgium, the United Kingdom of Great Britain and Northern Ireland, Iraq and Afghanistan. In 2050, more than $80 \%$ of the predicted 4.1 million foreign migrants in the Netherlands will come from Poland, Greece, Hungary, Turkey, Morocco, Indonesia, Germany, and the Russian Federation.

- France: this country (like the Netherlands) is characterized by a large number of sources of international migrants. In 2020 , the sources of $80 \%$ of international migrants (out of 7.3 million) in France will include eleven countries: Algeria, Morocco, Portugal, Tunisia, Italy, Spain, Turkey, Germany, the United Kingdom of Great Britain and Northern Ireland, Belgium and Madagascar. In 2050, more than $80 \%$ of the predicted 10.7 million foreign migrants in France will come from the same eleven countries, but in a slightly different order (in decreasing order): Algeria, Morocco, Portugal, Italy, Belgium, Tunisia, Spain, Turkey, Switzerland, Germany, and Madagascar. 


\section{Conclusions}

Thus, a forecast of international migration flows into European countries until 2050 has been described. As can be seen from the forecast data, European countries in the next thirty years will experience a gradually increasing influx of immigration. It should be noted, however, that, according to the forecast, immigration flows will be characterized by a low growth rate. The rate will be comparable to maintaining the status quo. This forecast runs contrary to populist statements about the massive, unstoppable influx of migrants into Europe.

It should be noted that a significant proportion of migrations take place within Europe itself, between European countries. For example, $80 \%$ of immigrants in Switzerland in 2050 will be from five European countries, of which only Serbia is not yet a member of the EU. Thus, although every second resident of Switzerland is predicted to be an immigrant in 2050, the Swiss government should not have additional causes for concern, as eight out of ten of these people will come from similarly developed European countries. In general, it can be stated that the vast majority of emigrants from EU countries will migrate within the EU's borders.

Obviously, thirty years is a long time, and therefore we can expect significant adjustments to the trends indicated in the forecast. Among the main factors that can cause the acceleration of migration flows is an acceleration of economic growth in the EU countries. Although such a scenario does not seem inevitable at present, it should not be discounted. Such an acceleration of economic growth can create two complementary levers for migration: (1) additional attraction for labor forces, and (2) a further increase in the level of social and medical support for EU residents, which will be accompanied by a continuing increase in life expectancy and, accordingly, an increase in the proportion of the elderly remaining within the working population. This second process will create an additional driver for labor migration. Paradoxically, slow or negative economic growth in EU countries should be considered a factor slowing down immigration to and within the EU. Forecasting the economic dynamics of EU countries is beyond the scope of this paper. However, it should be admitted that the presence of such a forecast would make it possible to clarify the forecast of migration flows. At the same time, the impact on migration of the current and projected economic dynamics of EU countries should not be overestimated. The current gap in the living standards of the EU and developing countries has created a significant reserve for economic migration, which is relatively small considering current levels of economic development.

Finally, an important and highly unpredictable factor affecting the accuracy of forecasts of migration flows into EU countries is the social legislation of the EU countries. The generosity of the welfare state in modern EU countries serves as a constant attracting factor for migrants from the least developed countries. Undoubtedly, legislatively reducing the size of social assistance guaranteed by the state can significantly reduce the attractiveness of the country for such migrants. One example confirming this is contemporary Ukraine. With all the attractiveness and richness of its nature, with the low cost of living in Ukraine, potential successful immigrants can hope for a state allowance of 0.5 euros per month, which does not look attractive even in countries such as Somalia. 
However, the consideration of the practical possibility of legislative limitation of guaranteed social benefits in the EU countries is beyond the scope of this paper.

It should be emphasized that the forecasts based on this model allow us to state that the problem of managing migration will continue for EU countries. However, the essence of this problem is not how to get rid of the influx of superfluous migrants, but how to attract migrants to the countries of the 'second Europe' - practically to all countries in Eastern Europe, as well as Portugal, which will experience ever-stronger depopulation. This depopulation will be intensified by the ever-increasing scale of intra-European migration.

\section{Bibliography}

Alvarez-Plata P., Brücker H., Siliverstova B. (2003), Potential Migration from Central and Eastern Europe into the EU-15: Report for the European Commission. DG Employment and Social Affairs, Berlin.

Bijak J., Disney G., Wiśniowski A. (2015), How to forecast international migration, ESRC Centre for Population Change, Briefing 28, October 2015, http://www.cpc.ac.uk/docs/BP28 How\%20 to $\% 20$ forecast $\% 20$ international $\% 20$ migration.pdf.

Carammia M., Dumont J.-Ch. (2018), Can we anticipate future migration flows?, Migration Policy Debates, OECD/EASO, no. 16 May, https://www.oecd.org/migration/mig/migration-policydebate-16.pdf.

Davis K. (1988), Social Science Approaches to International Migration. Population and Resources in Western Intellectual Traditions, eds. M. S. Teitelbaum, J. M. Winter, The Population Council, N.Y., pp. 245-261.

Disney G., Wiśniowski A., Forster J. J., Smith P. W. F., Bijak J. (2015), Evaluation of existing migration forecasting methods and models: Report for the Migration Advisory Committee, https://assets.publishing.service.gov.uk/government/uploads/system/uploads/attachment_data/ file/467405/Migration_Forecasting_report.pdf, 15.10.2018.

Isserman A. M., Plane D. A., Rogerson P. A., Beaumont P. M. (1985), Forecasting Interstate Migration with Limited Data: A Demographic-Economic Approach, "Journal of the American Statistical Association," vol. 80, no. 390 (Jun.), pp. 277-285, DOI: 10.2307/2287883.

Johnson S. B. (2018), Predicting migration flow through Europe, https://medium.com/@Simon_ B_Johnson/predicting-migration-flow-through-europe-3b93b0482fcd, 07.10.2018.

Migration forecasting (2018), https://migrationdataportal.org/themes/migration-forecasting, 22.10.2018.

Migration forecasting: Beyond the limits of uncertainty (2016), Global migration data analysis centre. Data briefing series, 2016, Iss. 6. November, https:/gmdac.iom.int/sites/default/files/gmdac_ data_briefing_series_issue_6.pdf.

Polovyi M. (2017), Forecasting the dynamics of the potential of international migrations by 2050, "Polski Przegląd Migracyjny," vol. 2, pp. 72-84.

Raymer J. et al. (2013), Integrated Modelling of European Migration, "Journal of the American Statistical Association," Iss. 108 (503), pp. 801-819, http://www.tandfonline.com/doi/abs/10.1080/ 01621459.2013.789435, February 2018.

Stone M. (2003), Prediction of future migration flows to the UK and Germany. Technical exercise, honest study, or convenient obfuscation?, http://www.civitas.org.uk/pdf/EUmigration.pdf.

Trends in International Migrant Stock: Migrants by Destination and Origin (2015), United Nations database, POP/DB/MIG/Stock/Rev.2015, United Nations, Department of Economic and Social Affairs, http://www.un.org/en/development/desa/population/migration/data/empirical2/migrationflows.shtml\#, June 2017. 
World Population Prospects: The 2002 Revision (2002), United Nations Department of Economic and Social Affairs. Population Division, vol. III: Analytical Report, 122, http://www.un.org/esa/ population/publications/wpp2002/WPP2002_VOL_3.pdf, March 2018.

World Population Prospects: The 2015 Revision (2015), United Nations Department of Economic and Social Affairs, Population Division, DVD Edition, File MIGR/2.

\title{
Prognoza przepływów międzynarodowych migracji do państw UE do 2050
}

\begin{abstract}
Summary
Tematyka prezentowanego artykułu dotyczy problematyki międzynarodowej migracji do państw członkowskich Unii Europejskiej. Celem badawczym artykułu jest ilościowe oszacowanie wielkości międzynarodowych przepływów migracyjnych do państw europejskich i ich bliskich sąsiadów do 2050 r. Autor posłużył się autorskim modelem migracji w skali globalnej. Opiera się on na synergicznym podejściu i założeniach, że poziom migracji określa przede wszystkim liczba istniejących imigrantów z tego państwa. W artykule wykorzystano dane ONZ dotyczące przepływów migracyjnych w latach 1990-2015. Umożliwiło to oszacowanie prognozy dotyczących m.in. zmian w populacji między rokiem 2050 a stanem obecnym. Prognoza ta opiera się na średnim scenariuszu rozwoju demograficznego ONZ. Jako potencjalne źródła imigracji autor wziął pod uwagę współczesne państwa o populacji powyżej 5 milionów. W przedłożonym tekście ujęto przewidywania dotyczące wartości całkowitej liczby przepływów międzynarodowych do każdego z państw UE i państw sąsiednich na każdy pięcioletni okres do roku 2050 oraz przepływy migracyjne z państw UE. Stwierdzono, że prognozy pozwalają nam twierdzić, że problem migracji będzie cały czas dotyczył państw UE. Jednak istotą tego problemu nie jest zapobieganie nadmiernej migracji, ale przyciąganie migrantów do krajów „drugiej Europy”.
\end{abstract}

Słowa kluczowe: prognozy międzynarodowych przepływów migracyjnych do 2050 r., Symulacja migracji międzynarodowej, migracja do UE 
